the caterpillars which live permanently in the dark, or those of the Microlepidoptera, just as little as those of the first stages of development of most butterflies, have no markings at all; their small size, or their habit of hiding themselves, sufficiently protect them from their enemies; they, therefore, need no markings to insure their safety. When the caterpillars are getting bigger the longitudinal streaks become useful, as through them they do not contrast so much with long-shaped leaves, fir. needles, or stems. The caterpillars with longitudinal streaks, such as those of Satyride, Pieride, \&c., almost without excep. tion live on fir-trees, grass, or plants growing among grass. The oblique streaks in the segments of other green caterpillars imitate the lateral ribs of the large leaves upon which these species live. The eye- and ring-shaped spots form another means of protection. On the one hand, they may imitate the berries of the plants on which the caterpillars feed, and protect the latter, inasmuch as the berries are still unfit to be eaten at that particular time (Deilephila hippophaes). On the other hand, the spots, greatly resembling eyes, most decidedly act as means of frightering the enemies of the larvæ; this is particularly the case with the Charocampa species, as, whenever any danger threatens them they draw their foremost segments into the fourth and fifth ones, and the eye-spots upon these then glare on the puffed-up fore-part of the animal. Weismann has proved this experimentally, by throwing such caterpillars as food before birds, and then watching the expression of fear on the part of the latter. There are other caterpillars the markings upon which cannot possibly be looked upon as means of frightening their enemies, as their repulsive odour or taste alone suffice to ward off the insectivora. Wallace has shown that such insects bear their many coloured marking like a stamp of their unfitness for food, and already by this frighten off insectivorous animals Weismann has proved by some experiments that lizards not only refuse certain caterpillars (Smerinthus, Sphinx, \&c.) at all times, but are even diffident towards others which are marked in a similar manner although quite edible, and only eat them after minute examination.

It is certain that many of these useful markings were acquired by natural adaptation (Naturzuechtung), and it is quite beyond doubt that others have resulted from the internal laws guiding the formation or growth of caterpillars, i.e., through correlation of the different parts of the insect, independently of all usefulness. This is proved by the retrograde movement of the markings acquired in later stages towards the earlier ones, where the markings can but be perfectly useless. The eye-spots, in the same way, first appear through natural adaptation near the head or the tail of the animal, and are then of use ; but later on they spread over the other segments also, and here they only reappear, because in articulata the general tendency exists to develop all segments in an equal manner. On the other hand the gradual disappearance of certain markings must be ascribed to natural adaptation, because under different conditions of life, more useful markings supplanted the existing ones, which had become useless. If the second phylogenetic form of the Sphingida caterpillars with single longitudinal streak, seems to indicate that the animals then lived on grass, these streaks became useless and even obnoxious when the caterpillars selected shrubs and trees for their food, and were then replaced by the more appropriate and useful eye-spots.

In short, as far as Weismann investigated the markings of caterpillars, particularly those of Sphingidle, he could prove their development to be caused by external influences (natural adaptation and subsequent correlation), and could consequently reject the assumption of a special creative or form-shaping power.

\section{D'ALBERTIS'S EXPEDITION UP THE FLY RIVER, NEW GUINEA}

THE Sydney Mail of Saturday, January 20, contains a long account of the expedition of the Italian naturalist, D'Albertis, up the Fly River, New Guinea, translated from his diaries, and communicated by Dr. George Bennett. Signor D'Albertis left Sydney, April 20 , 1876 , in the mail-steamer, Brisbane, and reached Somerset, Cape York, on May $\mathrm{r}$, where the steamlaunch Nevin, which had been provided for the purpose of the expedition by the liberality of the good citizens of Sydney, was disembarked and equipped. On May 19, after various small casualties, a start from Port Somerset was effected, and Katow, on the coast of New Guinea, reached on the second day. Hence the mouth of the Fly River, already well known to D'Albertis from his previous expedition in the Ellangowan, in 1876, was soon entered, and more or less progress was made every day. The land traversed appears to have been mostly low and swampy. On June 20 , being on shore, Mr. D'Albertis ascended a hill 250 feet high, and from the summit saw some "very bigh mountains" in the north. east, fifty or sixty miles distant-probably part of the "great Charles Louis range." On June 28, after having been for some time aground, and only got off by an unusually heavy flood, it was determined to return and to try the western branch of the Fly River. The strong current and other adverse circumstances rendered it necessary to abandon this attempt likewise, after about a week's struggle, and the Nevia returned to the coast, when the expedition passed several months amongst the islands, and finally returned to Somerset in November. The following is Mr. D'Albertis's summary of his discoveries :-

"After my long narrative I shall conclude with a few words expressing my regret at not having been able to do more. But it is often not the pioneer who shows the way that attains the most glory, but those who follow him; it is easy to hear of a road, but very difficult to find one out. I wish every success to any explorer of this part of New Guinea (should I not be able to return and complete my work), and I hope that the little I have done will be some guide and enable him to find his way more readily than I did mine, and to correct any errors I may have made. By this exploration we are now acquainted with a road into the interior of New Guinea, which is of the more importance, as it is so near to Somerset, where a line of large steamers calls twice every month. We have also found a passage from Moatta to the Fly. River, shorter and safer than the one previously known, and a passage which, when properly surveyed, may be found navigable for larger ships. The richness of the land we visited, its vegetable, and probably mineral, products, the soil suitable for many of the most valuable plants, as coffee, sugar, cotton, indiarubber, sago, tobacco, nutmeg, \&c., ought to attract the capital of the colony to open up the country. The Dutch from their part of New Guinea, although on a small scale, derive some trade. The part of New Guinea into which we penetrated, was in latitude $5^{\circ} 30^{\prime} \mathrm{S}$, , and ran about 500 miles on the winding river, the course of which may be seen on the chart appended, and it almost forms a line of demarcation between that part of New Guinea claimed by the Dutch, and that remaining as yet unclaimed by any nation.

"About the Fly River, as far as I could judge, the natives appear less numerous than I have seen in other parts of New Guinea, and the land is cultivated in a smaller quantity, so that in this part of New Guinea the settler will not find the same difficulties which I have pointed out on former occasions when speaking of the southeastern peninsula, where the natives are more numerous, and possess and cultivate all the best land. I have appended Baron von Mueller's report on my collection of dried plants $;^{1}$ and on the return of Prof. Liversidge to Sydney he will report on the small collection of minerals, \&c., I submitted to him for examination. On a day not far distant I hope to give the ethnological report on the natives, their weapons, \&c., also on the mammals and the birds collected, the latter consisting of about fifty species, many of which are new, or only recently described from specimens obtained during my first visit to the Fly River. I have also a rich collection of reptiles, fishes, both of salt and fresh water, some beetles, and some fresh water and land shells. I confidently expect that the voyage of the Neva will be remembered by those who take an interest in New Guinea, and by the scientific world."

\footnotetext{
Some extracts from this were given in our last issue, p. 438 .
} 